\title{
RAGAM HIAS MOTIF BATIK MELALUI RELIEF FLORA CANDI BOROBUDUR PADA MAHASISWA PGSD FKIP UAD
}

\author{
Fery Setyaningrum, Heni Siswantari
}

Surel: fery.setyaningrum@pgsd.uad.ac.id

\begin{abstract}
His study aims to describe the implementation of the decorative reliefs of the Borobudur temple flora on the batik motifs of PGSD FKIP UAD students. The research method that will be used is qualitative with a case study approach. Data collection techniques were carried out by interview, observation, and document review. Data analysis techniques that will be used in the form of data reduction, data presentation and drawing conclusions. The results of the study were the implementation of various relief batik motifs through the reliefs of the flora of the Borobudur temple on the work of PGSD UAD students. The motifs that appear in the decorative motifs made by students are geometric and non-gemetric batik motifs combined with flora reliefs in the form of frangipani trees, lotus trees, banana trees and lotus trees. Student works are in the form of 2-dimensional works with the identification of elements of straight, curved, zigzag and irregular lines, geometric expressions, organic expressions, multi-angled faces, and irregular shapes. and tertiary, playing dark and light, applying the principles of composition work.
\end{abstract}

Keywords: Decorative Variety, Batik Motif, Relief

\begin{abstract}
ABSTRAK
Penelitian ini bertujuan untuk mendeskripsikan implementasi ragam hias relief flora candi borobudur pada motif batik mahasiswa PGSD FKIP UAD. Metode penelitian yang akan digunakan adalah kualitatif dengan pendekatan studi kasus. Teknik pengumpulan data dilakukan dengan wawancara, observasi, dan telaah dokumen. Teknik analisis data yang akan digunakan berupa reduksi data, penyajian data serta penarikan kesimpulan. Hasil penelitian terimplementasinya ragam motif batik relief melalui relief flora candi Borobudur pada karya mahasiswa PGSD FKIP UAD. Motif yang muncul dalam ragam hias karya mahasiswa berupa motif batik geometris dan non gemetris dengan dikombinasikan relief flora berupa pohon kamboja, pohon teratai, pohon pisang dan pohon lotus. Karya mahasiswa berupa karya 2 dimensi dengan identifikasi unsur kesenirupaan garis lurus, lengkung, zigzag dan tak beraturan, raut geometris, raut organis, raut bersudut banyak, dan raut tak beraturan, tesktur yg terjadi adalah tekstur maya/semu, warna didominasi warna primer,sekunder dan tersier, memainkan gelap terang, mengaplikasikan prinsip komposisi karya.
\end{abstract}

Kata Kunci: Ragam Hias, Motif Batik, Relief

\section{PENDAHULUAN}

Candi Borobudur adalah salah satu dari warisan dunia. Menurut sejarah, bangunan kuno itu dibangun oleh Wangsa Syailendra pada tahun 800-an Masehi. Berabad-abad kemudian, candi itu ditemukan pada zaman penjajahan Inggris, tepatnya pada 1814, di mana saat itu reruntuhannya ditemukan pada sebuah bukit yang dipenuhi semak belukar Walaupun sudah bertahun-tahun 
menjadi ikon pariwisata Indonesia, Candi Borobudur masih menyimpan jutaan misteri yang terpendam. Para ilmuwan masih berusaha mencari tahu siapa penggagasnya, siapa arsiteknya, untuk apa candi itu dibangun dan difungsikan, dan berbagai pertanyaan lainnya. Salah satu objek penelitian di Candi Borobudur adalah reliefreliefnya. Tercatat di sana terdapat sepuluh tingkatan relief yang terbagi atas empat cerita. Salah satu relief yang amat penting di candi Borobudur adalah Lalitavistara.

Relief ini menceritakan tentang kehidupan Sang Buddha sejak berada di kahyangan sampai turun ke dunia dalam wujud Siddharta Gautama. Selain itu, pada relief ini terdapat penggambaran kekayaan flora dan fauna Nusantara pada zamannya. Penting sekali pada tingkat paling dasar siswa dan calon guru dari siswa tersebut (mahasiswa) mendapatkan pemahaman mendalam mengenai hal tersebut.

\section{METODE PENELITIAN}

Teknik pengumpulan data yang akan dilakukan adalah dengan wawancara, observasi, dan studi dokumen. Untuk menjaga keterpercayaannya, penelitian ini menggunakan teknik triangulasi.
Triangulasi menggunakan sumber dan teknik. Dokumen yaitu setiap bahan tertulis ataupun film, lain dari record, yang tidak dipersiapkan karena adanya permintaan seorang penyidik. Pada penelitian ini, penulis akan menggunakan wawancara tidak terstruktur atau bersifat informal. Subjek yang akan diwawancarai adalah mahasiswa Prodi PGSD UAD semester genap yang mengikuti matakuliah Pendidikan Seni Rupa dan Keterampilan dari kelas E-G. Penelitian ini menggunakan teknik analisis data (miles dan Huberman, 1992) Jenis dokumen yang akan ditelaah meliputi foto, dokumen elektronik, dan video. Berupa reduksi data, ferivikasi data, penyajian kesimpulan.

\section{HASIL PENELITIAN DAN PEMBAHASAN}

Hasil dan analisis data yang telah dilakukan pada hasil karya mahasiswa PGSD FKIP UAD berupa ragam hias motif batik dengan motif flora yang ada di candi Borobudur adalah sebagai berikut, dari 3 kelas yaitu kelas E F G maka masing-masing kelas peneliti ambil sampel 3 karya untuk dapat dikaitkan dengan motif flora pada candi Borobudur. Berikut tabel identifikasi karya mahasiswa. 
Tabel 1. Identifikasi Karya ragam hias kelas $\mathbf{E}$

\begin{tabular}{l|l|l}
\hline Karya Mahasiswa & \multicolumn{1}{|c|}{ Identitas, Bahan Dan Alat } & \multicolumn{1}{c}{ Keterangan karya } \\
\hline & $\begin{array}{l}\text { Nama Friska Anggun Megita. } \\
\text { Bahan \& Alat: } \\
\text { Kertas gambar/kertas manila dengan } \\
\text { ukuran A3, pensil 2B, penghapus, } \\
\text { penggaris, pensil warna } \\
\text { spidol warna. }\end{array}$ & $\begin{array}{l}\text { Mengkreasikan motif ragam hias dari } \\
\text { batik bunga dan daun simpor yang } \\
\text { berasal dari daerah bangka belitung } \\
\text { dikombinasi dengan bunga dan daun } \\
\text { saroja yang terdapat dalam relief } \\
\text { candi borobudur. }\end{array}$ \\
\hline & $\begin{array}{l}\text { Nama Erika Agnistya Dewi } \\
\text { Bahan \& Alat: } \\
\text { Kertas gambar/manila ukuran A3, } \\
\text { pensil 2B, penghapus, penggaris, } \\
\text { Drawing pen, cat akrilik, palet, kuas. }\end{array}$ & $\begin{array}{l}\text { Mengkreasikan motif ragam hias dari } \\
\text { biji pinus dan kumbang } \\
\text { dikombinasikan dengan relief flora } \\
\text { candi borobudur tanaman lotus }\end{array}$ \\
\hline & $\begin{array}{l}\text { Nama Devita Fety Arumsari } \\
\text { Bahan \& Alat: } \\
\text { Kertas gambar/manila ukuran A3 } \\
\text { Pensil, sidol, Drawing pen, Penghapus } \\
\text { dan penggaris }\end{array}$ & $\begin{array}{l}\text { Mengkreasikan motif ragam hias dari } \\
\text { motof ceplok batik jawa dengan } \\
\text { kombinasi motif dalam relief candi } \\
\text { borobudur berupa pohon pisang. }\end{array}$ \\
\hline
\end{tabular}

Berdasarkan tabel di atas maka karya kelas E sebagian besar menggunakan alat dan bahan media kering berupa spidol, drawing pen, pensil warna. Sebagian lagi menggunakan media basah berupa cat akrilik yang dituangkan ke atas kertas gambar atau berupa kertas manila dengan ukuran A3.

\section{Tabel 2. Identifikasi Karya ragam hias kelas F}

\begin{tabular}{|c|c|c|}
\hline Karya Mahasiswa & Identitas, Bahan Dan Alat & Keterangan karya \\
\hline & $\begin{array}{l}\text { Nama Nadia Miftakhul Jannah } \\
\text { Bahan \& Alat: } \\
\text { Kertas gambar/manila ukuran A3 } \\
\text { Pensil, Penghapus, Pensil warna } \\
\text { Spidol hitam. }\end{array}$ & $\begin{array}{l}\text { Bentuknya mengambil batik khas Sleman yaitu batik } \\
\text { parijotho lalu bunga dan daun distilasi dan } \\
\text { kombinasikan menjadi bunga sepatu karena di } \\
\text { daerah Godean (salah satu kecamatan di Sleman) } \\
\text { banyak yang menanam bunga sepatu. Bunga sepatu } \\
\text { sendiri yaitu salah satu relief yang ada pada candi } \\
\text { Borobudur. }\end{array}$ \\
\hline & $\begin{array}{l}\text { Nama Rizky Intan Khoirunissa } \\
\text { Bahan \& Alat: } \\
\text { Kertas gambar/manila ukuran A3. } \\
\text { Penghapus, Penggaris, Kuas, palet } \\
\text { Cat air/akrilik, Air bersih, dan Spidol } \\
\text { hitam }\end{array}$ & $\begin{array}{l}\text { Bentuk dari ragam hias ini adalah motif kawung } \\
\text { yang terinspirasi dari batik yang banyak dijumpai di } \\
\text { daerah Yogyakarta. Kemudian terdapat bentuk } \\
\text { bunga sepatu yang merupakan kombinasi motif dari } \\
\text { relief yang ada di candi Borobudur. Dan terdapat } \\
\text { gambar bunga kamboja yang terinspirasi dari bunga } \\
\text { yang banyak tumbuh di daerah Yogyakarta. Dan } \\
\text { gambar daun terinspirasi dari daun bunga sepatu. }\end{array}$ \\
\hline & $\begin{array}{l}\text { Nama Kurnia Putri Nur Wijaya } \\
\text { Mukti. } \\
\text { Bahan \& Alat: } \\
\text { Buku Gambar/kertas manila A3 } \\
\text { Pensil Warna, Pengaris, Spidol, Pensil } \\
\text { 2B, dan Penghapus }\end{array}$ & $\begin{array}{l}\text { Bentuk ragam hias dari batik grompol Yogyakarta } \\
\text { dan batik salak sleman yang dikombinasikan serta } \\
\text { ditambah unsur tumbuhan yaitu daun dan bunga. } \\
\text { Selain itu, ditambahkan berupa kombinasi motif } \\
\text { relief yang ada di Candi Borobudur yaitu motif } \\
\text { Bunga Lotus. }\end{array}$ \\
\hline
\end{tabular}

Berdasarkan tabel di atas maka karya kelas $\mathrm{F}$ sebagian besar menggunakan alat dan bahan media kering berupa spidol, drawing pen, pensil warna. Sebagian lagi menggunakan media basah berupa cat akrilik yang dituangkan ke atas kertas 
gambar atau berupa kertas manila dengan ukuran A3.

Tabel 3. Identifikasi Karya ragam hias kelas G

\begin{tabular}{|c|c|c|}
\hline Karya Mahasiswa & Identitas, Bahan Dan Alat & Keterangan karya \\
\hline & $\begin{array}{l}\text { Nama Safira Razy Narulita } \\
\text { Bahan \& Alat: } \\
\text { Buku gambar/kertas manila A3 } \\
\text { Pensil 2B, Penggaris, Penghapus } \\
\text { Cat air, dan spidol }\end{array}$ & $\begin{array}{l}\text { Mengambil batik banjarnegara yang bermotif jahean karena } \\
\text { Tanaman jahe ini di budidayakan di daerah pegunungan di } \\
\text { sekitar Banjarnegara. Adapun unsur tambahan yaitu ceplok } \\
\text { dan untaian daun-daun unsur ini sebagai penyerta atau } \\
\text { pendukung ornamentik yang utama yaitu unsur flora. Motif } \\
\text { batik jahean di Gumelem dikombinasikan dengan corak } \\
\text { relief Borobudur yaitu pohon pisang. }\end{array}$ \\
\hline & $\begin{array}{l}\text { Nama Lelie azelia } \\
\text { Bahan \& Alat: } \\
\text { Buku gambar/kertas manila A3 } \\
\text { Pensil 2B, Penggaris, Penghapus } \\
\text { Spidol hitam, Pensil warna, dan } \\
\text { spidol }\end{array}$ & $\begin{array}{l}\text { bentuknya bunga sepatu karena terisnpirasi dari bung yang } \\
\text { banyak tumbuh didaerah Belitung,dan juga bentuknya yang } \\
\text { mudah untuk digambar,digambar tersebut juga ditambahkan } \\
\text { motif candi Borobudur bunga kamboja, untuk pewarnaan } \\
\text { menggunakan } \\
\text { kombinasi } 3 \text { warna. }\end{array}$ \\
\hline & $\begin{array}{l}\text { Nama Risma Waras Andani } \\
\text { Bahan \& Alat: } \\
\text { Buku gambar/kertas manila A3 } \\
\text { Pensil 2B, Penggaris, Penghapus } \\
\text { Spidol hitam, Pensil warna, spidol. }\end{array}$ & $\begin{array}{l}\text { Bentuk bunga kamboja jepang terinspirasi dari bunga yang } \\
\text { tumbuh di sekitar depan rumah, bunga tapak dara terinspirasi } \\
\text { dari bunga yang tumbuh disekitar rumah, bentuk batik } \\
\text { kawung terinspirasi dari batik di Jawa, bentuk burung } \\
\text { cenderawasih terisnpirasi dari kain batik yang saya punya, } \\
\text { dan yang terakhir terdapat kombinasi dari bentuk tumbuhan } \\
\text { seroja dalam relief candi Borobudur. }\end{array}$ \\
\hline
\end{tabular}

Berdasarkan tabel di atas maka karya kelas $\mathrm{G}$ sebagian besar menggunakan alat dan bahan media kering berupa spidol, drawing pen, pensil warna. Sebagian lagi menggunakan media basah berupa cat akrilik yang dituangkan ke atas kertas gambar atau berupa kertas manila dengan ukuran A3.

[K. \& A. Nia, 2019) batik merupakan salah satu cabang seni rupa dengan latar belakang sejarah dan akar budaya yang kuat dalam perkembangan kebudayaan Bangsa Indonesia. Salah satunya adalah di wilayah Yogyakarta dan sekitarnya.

Motif-motif yang terbentuk sebagai buah karya mahasiswa juga sebagian besar kombinasi dari motif geometris (meander, swastika, kait/kunci, tumpal, pilin/spiral, pilin berganda, guirlande), motif tumbuhan, motif hewan, motif awan dan batu karang, motif abstrak. Warna yang yang banyak dipilih merupakan perpaduan warna primer sehingga tersier tentunya disesuikan dengan ke khasan batik diwilayah masingmasing mahasiswa dengan kombinasi warna baru. Mahasiswa mengembangkan berbagai warna seusai imajinasi dan kreatifitas masing-masing (B. D. Regina, 2018). Pada penelitian ini tidak dilanjutkan hingga tahap pendesainan di kain maupun hingga teknik pewarnaan bahkan lainnya dikarenakan pembatasan penelitian, tahap tersebut akan dilanjutkan pada penelitian berikutnya, tahapan ini adalah tahap untuk penggambaran dna pematangan konsep batik terlebih dahulu (A. A. Trixie, 2020). 


\section{Pembahasan}

Karya masing-masing mahasiswa begitu berbeda satu dengan lainnya karena bersumber dari imajinasi yang tentunya berbeda (Hananto, Brian Alvin, 2018). Sebagian besar mahasiswa membuat karya berdasarkan ide motif flora/fauna yang terdekat dengan wilayah tempat tinggal kelahiran mahasiswa lalu dikembangkan dengan motof daerah lain dan mengangkat motof warisan dunia yang ada di candi Borobudur. Karya mahasiswa yang dihasilkan berbentuk karya geometris, seperti persegi, persegi panjang, lingkaran, segitiga, dan lainnya. Selain itu menurut Soegiharti ada juga motif lainnya selain geometris berupa motif manusia dan hewan serta tanaman $(\mathrm{T}$. Soegiart, 2016).

Desain dan konsep ragam hias ini nantinya akan dapat dikembangkan oleh mahasiswa untuk menjadi karya batik hingga proses akhir yaitu pelorotan jika mahasiswa menghendaki melanjutkan hingga tahapan tersebut (A. Asti, Musman \& Arini B, 2011). mengingat berbagai batik yang hadir di tengah bangsa Indonesia berangkat dari berbagai sejarah berupa pakaian oleh raja-raja maka perlu juga adanya iinovasi untuk bisa mempertahan khasanah budaya bangsa dengan melibatkan para generasi muda terutama berawal dalam Pendidikan dahulu agar bisa bertahan dan tetap mendunia dengan berbagai kreatifitasnya (Aliya, 2010).

Berdasarkan berbagai sampel yang sudah dimabil dari mahasiswa PGSD FKIP UAD sebagian berar menggunakan identifikasi jenis garis lurus, lengkung, zigzag atau tekuk. Untuk raut yang muncul dalam karya tersebut adalah sebgaian besar menggunakan raut menjadi (1) raut geometris, (2) raut organis, (3) raut bersudut banyak, dan (4) raut tak beraturan semuanya saling mengisi satu dengan lainnya. Warna yang dihasilkan juga banyak menggunakan warna primer, sekunder dna tersier. Tekstur yang ada berupa tekstur maya. Gelap terang yang dimainkan dalam karya juga muncul berdasarkan tone warna yang dipilih.

\section{SIMPULAN}

Hasil penelitian berupa terimplementasinya ragam motif batik melalui relief flora candi Borobudur pada kelas E F G dengan mengambil sampel karya secara acak masingmasing kelas diambil 3 karya, motif yang muncul dalam ragam hias karya mahasiswa berupa motif batik geometris dan non gemetris dengan dikombinasikan relief flora berupa pohon kamboja, pohon saroja/teratai, pohon pisang dan pohon lotus. Karya mahasiswa berupa karya 2 dimensi dengan identifikasi unsur kesenirupaan garis lurus, lengkung, zigzag dan tak beraturan, raut geometris, raut organis, raut bersudut banyak, dan raut tak beraturan, tesktur yg terjadi adalah tekstur maya/semu, warna didominasi warna primer,sekunder dan tersier, memainkan gelap terang dan menggunakan tone warna serta sudah memainkan prinsip seni rupa berupa kesatuan, keserasian, dominasi, 
keseimbangan, kesebandingan dengan maksimal.

\section{DAFTAR RUJUKAN}

K. \& A. Nia. 2019. Studi Tentang Motif dan Pewarnaan Batik Cap dengan Zat Pewarnaan Alam di Rumah Batik Dewi Busana Kecamatan Lunang Kabupaten Pesisir Selatan. J. Seni Rupa, vol. Volume 08, no. p-ISSN: 23015942 | e-ISSN: 2580-2380, pp. 303-307.

E. S. P. Giri. 2004. Ragam Hias Kreasi. in Handout UNY, Yogyakarta: UNY.

B. D. Regina. 2018. Mengeksplorasi Motif Batik Elephant Thailand menggunakan Teknik Shibori oleh Siswa SD Ban Krua Bangkok. J. Pemikir. dan Pengemb. SD, vol. 6 nomor 2, no. p-ISSN: 2338-1140, e-ISSN: 2527-3043, pp. 127-135.

A. A. Trixie. 2020. Filosofi Motif Batik sebagai Identitas Bangsa Indonesia. Folio, vol. 1 nomor 1, pp. 1-9.

A. Wulandari. 2016. Batik Nusantara: Filosofis, Cara Pembuatan \& Indsutri Batik. Yogyakarta: ANDI.

Hananto, Brian Alvin. 2018. Pengembangan Motif Batik Semarangan Menggunakan Tipografi Sebagai Gagasan Visual. J. Seni Reka Ranc., vol. Volume 1, pp. 1-18.

S. S. Soedewi. 2011. Teknik dan Ragam Hias Batik Yogya dan Solo. Jakarta: Yayasan Titian Masa Depan (Titian Foundation).
T. Soegiarty. 2016. Dokumentasi Dan Pemetaan Ornamen Batik Pesisiran Daerah Sunda Sebagai Sebuah Usaha Pelestarian Budaya Bangsa. PMI

A. Asti, Musman \& Arini B. 2011. Warisan Adiluhung Nusantara. Jakarta: Yayasan Titian Masa Depan (Titian Foundation).

Aliya. 2010. Batik Pekalongan. Jakarta Timur: Rama Edukasitama.

S. Ristiani, T. Sulistyaningsih, A. A. Wibowo, Syamsudin, and Sugiyanto. 2020. Batik Latar Ringkel. Yogyakarta: ANDI Offset. 